\title{
The Public Service And Good Governance In Nigeria's Fourth Republic: Pitfalls And Opportunities
}

\author{
Ighodalo Akhakpe \\ Department of Public Administration \\ Faculty of Management Sciences \\ Lagos State University, Ojo, Lagos, Nigeria
}

\begin{abstract}
The public service of any nation is conceived as a driver of policies and programmes of government that is aimed at promoting the welfare and well-being of the people and the corporate existence of the State. It is against this back-drop that the return to civil rule in 1999 was seen as an opportunity to stem the tide of socio-economic and political decline in Nigeria. However, more than a decade and half of democratic rule, the citizenry still wallow in abject poverty, insecurity, unemployment, electricity power supply, poor medical care and shelter, corruption, feeble enforcement of transparency and accountability, exclusion of the citizenry from decision making and legitimacy crisis. With the use of political participation theory, the paper observed that the public service is still largely disconnected from the people that it is meant to serve. In most cases it pursues its self-interest rather than the public good. This largely accounts for its assumed abysmal records bad governance in the delivery of democratic dividends across the country. The paper made far-reaching recommendations on how to bring the country out of this unpalatable situation. These include among others: the promotion of core-democratic values, prioritization of professionalism in the public service, capacity building for public servants, promotion of the new public management principles, zero tolerance for corruption, political stability, participatory decision making and promotion of distributive justice. It concluded that regime change also demands change in the attitude, structure and operational dynamics of the public service in order to promote good governance in Nigeria.
\end{abstract}

Key Words: Public Service, Democratic Governance, Service Delivery, Professionalism and Development.

\section{INTRODUCTION}

The public service of any nation is the hub that keeps the governmental machine running and ensures that policies and programmes of government are persuaded and realized. Modern societies have become more complex and dynamic. Demands for goods and services are changing by the day. The public service needs also to change its structure, organisation and operations. It needs these changes in order to respond adequately, efficiently and effectively to the essential needs of the people. Unless it comes to terms with these operative needs, it may find itself racing against time in terms of delivering quality services to its clients. The goods and services the public service provides are contained in policies and programmes of government and are expected to meet the present and future needs of both the government in power and the society. Its clients are the citizenry who are the essence of any government. (Dibic, 2014)

However, many years after independence, the Nigerian state and its citizens appear not to have progressed much in terms of availability of the good things of life such as: security, portable water, shelter, food, good roads, qualitative education, reliable electricity supply and medical care for the young and old in the society. Most of these short-comings in the governance 
system of the society are often laid at the door steps of the public service that is often credited with the responsibility of moving the craft of public administration to safety in terms of efficient delivery of policies and programmes of government at all times.

Prior to the attainment of independence in 1960, it was the consensus of the federating regions of the country that there should be public services in all the regions and later the states and at the federal level. In the light of this, there are presently thirty-six (36), public services and a central one. Be that as it may, the material conditions or social concerns of the citizenry in particular and developments of the country in general have not been substantially realized. In spite, of the country's abundant wealth, it remains one of the poorest in the world with a population that lives on less than one dollar per day. In the course of the present economic recession in the country, the living conditions of the citizenry have declined further.

However, with the return to democratic rule, it is expected that the public service will extend the frontier of the core democratic values of popular participation accountability, legitimacy and political freedom. These are core ingredients for any public institution's efforts at development. In the light of the above, the essay examines efforts of the public service to deliver good governance in Nigeria, the interplay of forces under democratic rule, obstacles on the path of the public service in promoting the good governance and opportunities available to it with the opening of the socio-economic and political spaces in the country to promote good governance.

\section{METHODOLOGY}

The method employed in this investigation is essentially exploratory. Content analysis will be used with materials drawn from periodicals and archival sources. Indepth interview method will also be used to elicit views of top public servants and the political elite in the present democratic dispensation. Further, the participant observatory method will be employed as the author is also a client of the public service goods and services and a player in the democratic system.

\section{CONCEPTUAL AND THEORETICAL EXPLORATION}

Conceptualizing and theorizing social phenomena in the social and management sciences are scientific exercises that aim principally at giving intellectual directions to issues under investigation. They help to comb the various contours of scientific constructs with a view to situating them within the purview of scholarly discourse and analyses of the subject matter of inquiry.

The public service is that institution of government set up in a civil capacity to discharge the responsibility of a state. Bankole (2010) defines the civil service as the service of the federation in civil capacity. In Nigeria there is a civil service for each State of the federation and a central or federal civil service. The federal civil service include: the President, Vice President, Ministries and extra-ministerial departments charged with the responsibility for any business of the government of the federation. Part IV, Section 318 (1) of the 1999 constitution defines the civil service as the civil service of the federation (State) in a civil capacity as staff of the office of the President, the Vice President, a ministry or department of the government of the federation (State).

However, the public service is a term sometimes used interchangeably with the civil service. In terms of definition they may not mean the same thing but operationally they intercept at various points. The public service may be regarded as a broader term than the civil service in that it embraces the commission services of government either at the federal or State levels. 
The 1999 constitution under the Executive Part I (D) and Part II (c) provide for a public service at the federal and state levels (Bankole, 2010). It includes: judicial officers, board and officers of the statutory corporations or companies in which the government stake. Also, it includes members of the Armed Forces, the police or other government security agencies established by law. It would seem the public service is a term that encapsulates the civil service under its canopy (Maduabum, 2006). Maduabum (2006) opines that "we could therefore, say that there is an umbilical cord that strongly link the ministries (civil service) to parastatals". Thus, while all civil servants could be public servants, all public servants are not civil servants. Maduabum (2006)

All modern states or nations have embraced democracy and good governance frameworks for organizing their societies. Democracy in its contemporary connotation is regarded as government of the people through their representatives. While in the era of classical democracy, everybody took part in decision making, in contemporary times indirect or representative democracy is the norm due to increase in population and among other reasons. Therefore, periodic elections are conducted to choose official leaders for a specified term in office. Similarly, governance has become a complementary term usually associate with democracy. Several notions of governance could be found in the literature. From a broad perspective, governance can be described as the use of public authority and resources to meet societal ends efficiently and effectively. Kaufmann (2000) defines governance as "the exercise of authority through formal and informal traditions and institutions for the common good. Furthermore, governance is the process of selecting, monitoring and replacing government, it includes: the capacity to formulate and implement sound policies and the respect of citizens and the State for the institutions that govern economic and social interaction(s). (Kaufmann, 2000) provides a definition of governance by the United Nations Development Programme (UNDP, 1997) notes that it is "the exercise of economic, political and administrative authorities to manage a country's affairs at all levels". The aim of this exercise apparently is to serve the common good.

When democracy and governance are joined together, it becomes democratic governance. The essence of this marriage is to extend the frontier of the citizens' welfare and the overall development of the human society. In the opinion of Nzongola-Ntalaja (1997), democratic governance is said to have the following recousive elements: the rule of law and constitutionalism, legitimacy of the government in power, transparency and accountability by those exercising political power, right of the citizens to exercise civil and political activities, for example, to elect and or replace their leaders, decentralization of power and resources in the State and freedom or independence of associational groups from the State (Akhakpe, 2014). Under civil rule, the public service is to ensure that these core values of democratic governance are pursued and realized in the interest of the people and society. It is important to note that in doing these, public servants are expected to be a political that is, they should be unbiased in serving all governments that comes to power with equal commitment and dedication.

Several theories may provide adequate framework for a study of this nature. They include the system theory, the state and society relation theory, the political culture theory, popular participation theory, etcetera. However, for our purpose in this essay, we shall adopt the popular participation theory that emphasizes the role of the citizens as active participant in matters that affect their individual and collective welfare and well-being. It sees the citizens of a State as the essence of government. Therefore, deliberate efforts are to be made to involve them and gain their support in the process of policy initiation, policy making and policy implementation. They are to be seen as not just end products of government policies and programmes but active participants in the process leading to them (Ake 1994). This theory is 
in line with the bottom-up approach to development and governance. However, as Almond et al (2005) have observed, most citizens have low political efficacy due to their parochial political orientation and consciousness. This is particularly true of Africans who perhaps due to their relative poverty and illiteracy involve in the political process only at election time thereafter, they do not defend their votes or participate actively in public affairs (Henry, 2007). Be that as it may, for the dividends of democracy to be realized in the society, there is no gainsaying that recipients of these dividends should be involved directly in the process in order to achieve the goal of good governance.

\section{Public Service and Professionalism}

The complexity of modern government and demands of the times have made it expedient to continually emphasize the imperative of a professional public service. This concern is given the fact that more than ever before, quality services are been demanded by the people who are eager to enjoy the dividends of democracy they sacrificially gained in 1999 after many years of military rule. At the centre of these expectations are the needs for a responsive, accountable, talented and productive public service. To all these can be added the imperative of merit in the recruitment and promotion of public servants. To a large extent, these goals have been pursued by successive governments, though their outcomes have not reflected the enormous amount of time and resources expended on them. This submission can be gleaned from the performance evaluation made on the public service under democratic rule with special focus on the economy. In this regard Adamolekun (1997) observed that:

The gross mismanagement of the nation's resources and the insecurity and irresponsibility of the political leadership reached a point at which silence could not have been considered golden in every instance. Consequently, the verdict is inescapable that the senior administrators (public servants) share part of the blame for the mismanagement of the national economy....

The public service should be the conscience of the people. Public servants should always speak out and defend the public interests irrespective of the government in power. Perhaps, the selfserving role of public servants has blurred these public values. The rat-race for material wealth in the polity has perhaps, caught up with the public service as shown in the rising "phenomenon of silent but wealthy public servants which some observers have noted could have been most likely derived from collusion between civil servants and politicians in the race for wealth accumulation" (Adamolekun, 1997). Under this circumstance, good governance could most likely be put in abeyance and suffer set backs

Henry (2007) has suggested that the window of opportunities for financial gains in the public service under the present spoil system in our polity can be closed through the return to rigid application of administrative principles and the installation of well-planned organizational structure and processes...." These measures have the ability to focus the public service on its core duties and responsibilities rather than move it towards prebandal politics as is being observed under the present democratic dispensation. Corruption still remains pervasive as tax payers' motives are used by public executives to pursue personal interests. In this circumstance, good governance suffers irreparably just as it was in the immediate postindependence years.

Therefore, there is an organic interface between the public service's professionalism and good governance. Given the exigencies of the time, more responsiveness of government is required to meet and satisfy the demands of the people for quality goods and services. Thus, Stealfer (in Afegbua 2015) suggests that professionalism of the public service entails three recursive elements. Substantive law that provides the framework for decision making, public officials are 
exposed to sources of information and tools to implement such information; the quality of procedural legislation is high enough to facilitate coordination and balancing of power. Also, the case of communication with members of the public thereby giving them opportunities to have their say on matters that affect them; and emphasis on the quality of financial and administrative accountability, control mechanism to ensure transparency, financial and administrative decision making and activation and use of the means of correction, persecution and address of administrative actions, are all germane to a new public service that can promote good governances in Nigeria.

However, experiences have shown that while there are well thought and properly codified rules, laws and ethics of administrative governance, public servants appear to lack the innovativeness and creative instincts and minds to domesticate and actualize these body of ordinances for the good governance and development of the polity. It is against these backdrops that scholars have opined that moving forwards, public servants should embrace innovative and creative style of management well attained to societal growth, development and social well-being of the people (Maduabum, 2014 and Yusuf and Idowu 2017).

\section{The Public Service and Good Governance}

The essence of any government is to ensure the welfare and well-being of its citizens. Public policy should strive to bring this imperative to bear on the life of the people and society. However, if the state of social welfare in the country is anything to go by, it would seem not much have been done or achieved in this regard. This has made it imperative for public policy reform to be carried out. To achieve the goal of policy reform that has as its ultimate goal better service delivery, there should be best practices in administration. As Dibie (2014) has shown, the New Public Management (NPM) principles were initially evolved with recommendations for the application of competitive market and economy in the actions and activities of government. If faithfully carried out they have the potentials of making government activities efficient and effective.

However, good governance variant has perhaps come into reckoning because it seeks to extend the frontiers of the NPM by embracing the bigger picture of the political space to make the process of reform all-encompassing. Adamolekun (in Dibie 2014) identifies the main elements of governance as captured in the public administration literature to include: freedom of expression and association, rule of law; electoral legitimacy; transparency and accountability and development oriented leadership. While the early form of public sector reform under NPM took the form of privatization of public firms and services the governance reform seeks to bring the hitherto, alienated citizenry into the midst of decision making that affects their individual and collective interests.

This perspective to governance has become popular particularly in the developing areas of the world where authoritarian governments hitherto, held sway. The citizens and voluntary associations in these societies were isolated from governance and public resources were used and continue to be used without recourse to public accountability and transparency. This has made it necessary to emphasis the sub-type of good governance that implies the management of state or government resources for effectiveness and equitable distribution of public resources. 


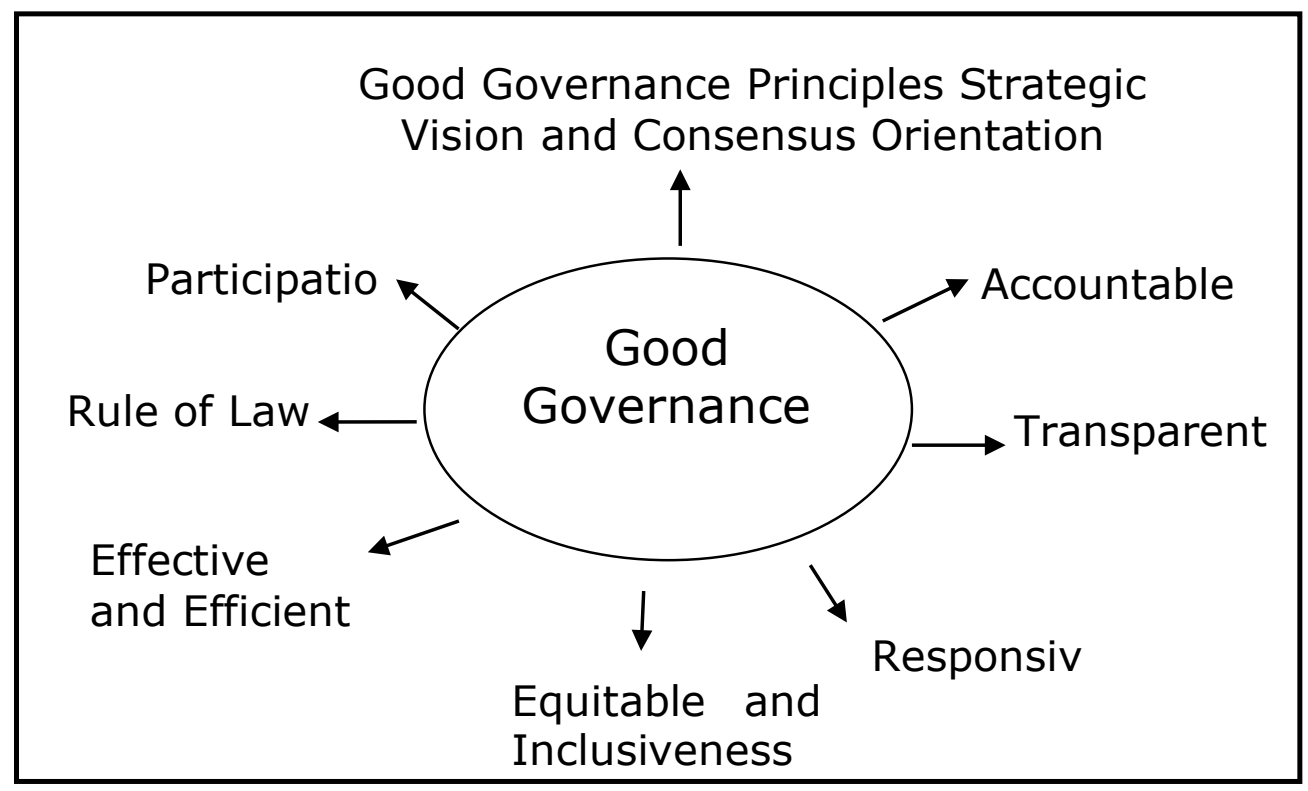

Source: Sarumi, 0. 2016.

These principles as shown above are not new in the public sector, especially under the governance agenda. Various governments seek to make the public sector more performance driven and productive. However, this cannot be realized if the citizenry are isolated and resources used inefficiently and ineffectively. Therefore, to achieve these principles of good governance as depicted in the diagram above, certain measures have to be put in placed.

\section{Strategies for Implementing the Good Governance Principles}

In pursuance of the goals or principles of good governance, certain practices have evolved. These include:

- Re-directing priorities of the state towards investment in human needs in the areas of social safety nets for the poor and marginalized;

- Strengthen state institutions;

- Introduction of reform in the functioning of parliament and increasing its effectiveness;

- Enhancing civil service capabilities through appropriate reform instruments that match performance with accountability;

- Creating new alliances with civil society organisations; and

- Evolving a new partnership framework for government - business cooperation (Sarumi 2016).

While these strategies are plausible and garmane to public service performance and good governance in the society, a performance review of the public service and good governance in the body politic will show that their implementation has been poor or abysmal due to several constrains that include: mal-distribution of resources, managerial credibility gap, behavioural hazard, lack of capacity building among others. However, with the inauguration of the Fourth Republic of Nigerians, hopes have been rekindled. Yet, it is not clear how the public service is handling opportunities available to it to leverage on in bringing about sustainable national development. Perhaps, only a careful perusal of the interface between the public services and democratic governance will reveal this.

\section{The Nature of the Public Service and Democratic Governance}

The public service especially under the Westminster Model that the country practices, is one of the migrated or transplanted institutions from Europe that came to the country in the course of 
colonial rule. The public service, weaned in the Western culture has been effective in running governments in Europe and North America. In the course of colonial rule in Nigeria, it was introduced by the British colonial administrators under a philosophy, a one time Governor General of Nigeria - Lord Lugard called the "Dual Mandate" (Adamolekun, 1997). It states that European brains will be used to develop the native people in exchange for their raw materials such as oil, solid minerals and agricultural produce. This sounds more like the policy of reciprocity. Yet, it has always been the case even in the post-colonial era. However, this policy has been implemented to the detriment of the ex-colonies in Africa, Asia and Latin-America.

The machinery to execute this mandate was the public service. The public service in Nigeria has the characteristics of permanency, anonymity and impartiality. These characteristics, it would seem are to enable public servants serve the interest of the nation and its citizens efficiently and effectively. According to (Adamolekun, 1997) these principles were justified on the grounds that:

The political maturity of the public service is a fundamental feature of British democratic government and is essential for its efficient operation. It must be maintained even at the cost of some loss of political liberty by certain of those who elect to enter the service.

Unfortunately, this requirement has not engendered efficiency in the services. Several factors may explain this condition of the public services. Perhaps, the West-Minister model of the public service is more suited for a parliamentary system of government and a context where pattern maintenance is most required in the system. However, this can not be said to be the case in Africa where the continent is urgently in need of adaptation and integration of imposed political and/or administrative system. Also, given the need for accelerated development of the new States in Africa, effectiveness might have been prioritized over efficiency. It then becomes a question of how well the inherited public service model could adjust to the imperative need of the emergent State. Besides, the clamour for independence led to pressure from the elite to Nigerianise the public service. This led to the exit of experienced expatriates from the public service, thereby, leaving behind managerial gap that were hurriedly filled by less than competent indigenous officials across the regions and later states in Nigeria.

Gboyega (1992) and Adamolekun (1997) have observed that the periods before independence were eras of successes and high level performances of the public service. Although the public service was compact, it carried out its responsibilities efficiently. However, shortly after independence, the public services in the country began to post poor performances. This was partly due to increase in the public services by virtue of the existence of four regions, the emergence of ethnic politics and low calibres of available human capital. Politicians become too engrossed in matters of politics than fashioning out policies and progrmmes of development in the political society. Public servants on their part were quick to capitalize on this lacuna created to foster and consolidate their self and organisational interests (Ademolekun, 1997). Thus, several development plans established after independence did not further the frontier of good governance in the country. Consequently, neo-patrimonialism, prebendalism and legitimacy crisis led to the breakdown of law and order that culminated in the first military coup in 1966.

The ensuing civil war in the country led to the emergence of the military- civil service complex. This became glaring after the civil war as those known as super-permanent secretaries in the public service constituted themselves into a club that canvassed for the continuation of military rule under a one party system. In the main, this was meant to promote their own interest that has gained primacy following the absence of elected political leaders. Of course, in 
the context of all these, democratic governance was neglected. The ideal of people's participation in decision-making was put in abeyance, the citizens rights were curtailed, the constitution was suspended and there was free for all scramble for the resources of the State by the military men, bureaucrats and civilians in the prescient and corridors of political power. Consequently, a social distance was created between public servants and the citizenry they are suppose to serve (Olugbemi, 1979). It is no surprise that the good governance expectations of Nigerians have not be realized even in the Fourth Republic. According to Olugbemi (1979) the reason for this lies in the clash of interests between the public servants and the State on the one hand and the citizens on the other. As Olugbemi (1979) argues:

...the thesis is submitted that in so far as the interests of the Nigerian State are distinguishable from the collective and/or sectional interests of the members of the civil society, Nigeria's higher public servants will exploit its role to further and protect its corporate interests...

It would seem public servants have exploited its role to made its corporate and personal interests. For example, over the years this conspiracy theory has led to criticisms of the public service as being part of the process of capital accumulation ravaging, the Nigerian polity. Also, this trend, according to Amuwo (1997) has led to the public service being accused of "insensitivity to the reality of the society". In essence, those clientelist and neo-patrimonial nature of the peripheral State in Nigeria have created room for the civil bureaucracy to expand its socio-economic and political influences more than bureaucratic norms could ever allow or entertained in the West..

It is no surprise therefore that the performance and responsiveness of public servants to issues of good governance has been less than impressive. As former President Olusegun Obasanjo rightly observed in his address to members of the Presidential Retreat on Service Delivery held in Abuja, he posits (in Maduabum, 2014) that:

...Regrettably, Nigerians have for too long been feeling short-changed by the quality of service delivery. Our public officers have for too long been showcases for the combined evils of inefficiency and corruption whilst being impediments to effective implementation of government policies...

The blame for this state of affair in public service delivery would appear to be laid on the door steps of civil servants in particular and public servants in general, who see themselves as "Lord" or part of the hegemonic class that is merely doing the citizenry a favour (Amuwo 1997). However, the Presidential address is just one of many such addresses that have failed to be translated into change of attitude and approaches to service delivery by public servants in the Ministries, Departments and Agencies (MDAs) of government.

\section{The State Of Governance in Nigeria's Fourth Republic}

The return to civil rule in 1999 marked another milestone in the evolution of the Nigerian State. It came against the backdrop of more than a decade and half of military dictatorship. For the up tenth time, expectations were high that the return to civil rule will stem the tide of socio-economic and political decline in the country. However, these expectations appear to have been dashed with the free fall of the standard of living of Nigerians. Political impunity is on the ascendency as elections into political offices has become a do or die affair or close to warfare. Poverty is on the rise due to food shortages, unemployment and inflation. Social infrastructure are in pitiable conditions with declining electricity supply, bad roads, poor medical facilities and the prevalence of water borne diseases arising from lack of portable water. 
On top of all these, government at the center is getting increasingly restive and impatient of opposition forces in civil society as its performance rating nose-dives. Its failure to improve on its economic and political performances have led to the crisis of legitimacy. Yet, government finds it convenient to breach the rule of law and constitutionalism by disobeying court orders and failing to follow the dictates of the constitution especially, in appointments made into key institutions of the State. While the present administration has made the anti-corruption crusade its key policy agenda, it appears in this fight to be selective as it moves increasingly towards political vendetta or witch-hunting of perceived or real political enemies of the government. In all these, freedom of the individuals are willfully trampled upon while transparency and accountability fail to mediate the governance process. The situation could have been different, if the public service has risen to the challenges of good governance in the country. Surely, there are obstacles to the public service achieving the corporate interests of the State and its citizens. In the next section, we direct our focus on these normative and empirical obstacles.

\section{Pitfalls to the Role of the Public Service in Good Governance}

In the preceding section, we analysed the nature of the public service in relation to good governance in the Fourth Republic. We observed that not much has changed in terms of how the public service does or carry out its operations, particular under the present democratic dispensation. It does appear there are pitfalls on its paths to achieving good governance. This is the subject of analysis in this section.

It is imperative to note that structural and ideological constraints remain the bane of the public service in fulfilling its obligation to the Nigerian State and its peoples. The West-minister model of the public service is structured to suit the parliamentary system of government under which there is collective responsibility. In this system, the failure of a government policy could lead to the fall of that government at any point in the life of the regime in power. This is not the case with the Presidential system where the President is elected for a four years tenure and he/she is responsible to the people during his/her tenure in office. To operate a system suited for a Parliamentary government in a Presidential one, creates structural and organizational problems which the 1988 civil service reform attempted to resolve without success. Also, the social distance between top public servants and ordinary Nigerians, shows that their interests are diametrically oppose, leading to the former pursuing its own corporate and personal interest (Olugbemi 11977). They have become a class in themselves rather than for themselves (Amuwo 1997).

Ekeh (1980) and Basil (1997) have both argued that the public service like other political institutions that migrated or transplanted from Europe were dead on arrival because they came disembodied of their encasing ethos and mores that made them efficient and effective in Europe. Thus, what we have today in Nigeria as the public service is not a true replica of what is found in Europe rather it has taken its own form that has neither the European values nor the Africa moral order that mediated pre-colonial governance structure and ideology. Basil (1997) argues that the scenario where the public service operates in Europe is quite different from that of Nigeria. The scenario, under which the public service operations in Europe is embedded in its cultural values which could not have been transplanted to Nigeria. Therefore, the public service in Nigeria is caught between the "devil and deep blue sea". In all intents and purposes, the public service in Nigeria is neither European nor African.

Another major pitfall in the public service quest for good governance in the country, is the decline in professionalism in the service. The primary role public servants hav to play in policy making and implementation, lacks the high level professionalism associated with the colonial 
public service (Adamolekun 1997, Olaopa 2010). As a perspective observer of the infamous era of "military-bureaucracy complex" put it (in Adamolekun 1997):

For too long public servants especially in the upper reaches of the service have had things their way. Not only were they involved in the normal execution of policy, they were to a considerable degree, the actual formulators of policy. This is of course contrary to their traditional (and professionalism).

The fallout of this development is that the public service became an institution too difficult to be tamed or checkmated by successive governments in the country. In pursuance of their selfperpetuating goals, they have succeeded in building a glass wall between them and the populace they are employed to serve. Consequent upon these developments professionalism in the service has suffered damages as public servants abandon their professional callings in search for the filthy lucre of the requisite of power or capital accumulation. As Olaopa (2010) argues that the (service) as a result of various events after independence as related above are derailed from the path of professionalism on which it was set up by the British colonialists. The immediate result of all these is the failure of the service to prop up the legitimacy of the government in power, execute developmental policies and programmes faithfully to improve the material conditions of the people, ensure security of life and property of Nigerians, create an atmosphere of inclusive decision making, respect for the rule of law and constitutionalism, transparency and accountability in governance, among other goals or ends of the political society (Henry 2007, Dibie 2014, Akhakpe 2016).

It would appear the pre-eminence of public servants in policy formulation and execution gave them the leverage to resist any effort aimed at reforming the service for better performance and efficiency in the delivery of their core mandate. Yet, there have been several administrative reforms exercise in the colonial and post-colonial eras but none of them have been able to bring the service to speed with its homologue in the advanced countries. In the words of Idode (in Igbugor 1998):

Unfortunately the various administrative reform exercises which were intended to maximize efficiency and effectiveness of these bureaucracies (Federal and States) merely produced counter-results, due to emphasis on material rewards (salaries and benefits) of the reforms, conflict of interests between bureaucratic functionaries, and diversion of energy from...development efforts to the struggle for control and authority.

Two not unrelated challenges flow from the above submission. Firstly, there is apparently an absence of a sound reward system that makes public servants to usurp every opportunity to improve their material well-being to the detriment of generality of Nigerians. Secondly, as a consequence of the aforementioned point, the focus of public servants appears to be diverted from service to the nation-state to struggle for control and authority within the organisation and outside it. This lack of supporting ethos that encase the public service has left it lay bare as mere paper tiger.

Moreso, corruption and neo-patrianomalism or patrion-client relations have become an albatross to the efficiency and effectiveness of the public service. President Mohammed Buhari has had cause to bemoan the role of public servants in corrupt practices, when he observed (The Punch, September 8, 2016) that:

Many...mourn the decline of the public service from the days as primus inter pares in the commonwealth to one which has earned a reputation for inefficiency, low productivity, corruption and insensitivity to the need of the public... 
Perhaps these maladies besetting the public service is not unrelated to its inability to adjust its vision and "modus aperandi" to cohere with the "shift in all aspects of the original (socioeconomic and) political equilibrium" in the country (Fukuyama, 2012). The service has failed to clearly articulate a vision based on the present and future needs of the Nigerian State and its people. The law and order nature of the service has not given to a more proactive and interventionist public service. This point is well made by Lapalombara (1967) when he enthused that:

The time is evidently past when public officials are expected to sit on the development side lines, limiting their roles to the fixing of general rules and to providing certain basic services and incentives for those private entrepreneurs who are the major players in the complicated and existing game of fashioning profound changes in economic and social systems.

The present condition of our society demands that public servants should be more interventionist. However, in many respect, public servants prefer to hide under the cover of official anonymity and maintain the statuo quo while the citizenry suffer under the weight of economic recession, social dislocation and political upheaval. Public administration in the globalize era has gone beyond law and order or night watchman's role to a system restructuring and interventionist roles in the pursuit of good governance in the society (Echikwonye and Kwaghaga 2011; Akhakpe 2016).

Elections are largely regarded as barometers for assessing, validating or removing nonperforming governments under a democratic system. However, in Nigeria, elections are fast becoming a fading shadow of democracy as they are often characterized by among others: violence, rigging, intimidation, inadequate and poor electoral administration. Much of these exercises involve public servants whose role has undermined the electoral process rather than promote it. Militarization of elections in the country is a testimony of the failure of the public service to comport the behavior of political contestants as well as the electorates. Good governance may not be realized where the electoral process cannot put in power the people's choice and promote the legitimacy of the administration in power.

\section{Public Service and Good Governance: The Opportunities For Change}

Much have been discussed in the preceding section on the pitfalls of the public service in its endeavour to achieve the goals of good governance in the society. However, with the continuous opening of the democratic space, there are emerging opportunities that could be harvested for socio-economic and political transformation in the polity. In this section, we focus on these opportunities by interrogating how they can help realize the short and long term goals of the Nigerian nation - state.

It is important to state from the on set that public servants should quickly align themselves with the democratic values of the present dispensation. The political equilibrium has shifted from the military command and obey system to democratic processes that require constant engagement with the people who are the essence and custodians of political power. Though one would expect some left over of military values to moderate activities of the public service, this should begin to change with the consolidation of democracy in the country. However, this will demand that elections under this system should bring to power the choice of the electorates who can pursue and deliver dividends of democratic governance in the polity. Again, the public service should be the game changer in this process through proactive engagement of stakeholders in the governance process. 
Also, it is expected that the attitude of public servants would change in the positive direction particularly, by subordinating their personal interest to that of the public. The materialist perception of the state as an entity whose resources belong to none and are inexhaustible should give way to patriotic and nationalistic views of the State with public servants showing willingness to embrace international best practices in public management and good governance (Osaghae 2002, Akhakpe 2017, Maduabum 2014).

One area that this change should be clearly felt is in how public sector organisations are managed. Every nation would want to put its best foot forward! To achieve this goal, the best hands should be appointed into public organisations in order for the goals of good governance to be realized. Nobody gives what it does not have. The practice of appointing people into public offices on the bases of neo-patrimonial considerations can only lead to mediocre results. The best hands should be recruited from every part of the country. In this regard, the federal character principle should not be allowed to diminish the efficacy and indispensability of the merit system (The Punch, 25/10/2016).

The return to professionalism is surely the gate way to efficient and effective service delivery and good governance. Performance of the public service would remain low insofar as professionalism and innovation are relegated to the background (Afegbua 2015). Capacity building and constant pursuit of innovative style of management are necessary ingredients for tackling challenges of a complex and dynamic world (Maduabum 2014; Afegbua 2015 Akhakpe 2016). As President Buhari recently noted, the problem of the civil and public services in Nigeria is that of "inability to articulate a vision and develop the required capacity to implement such vision (The Punch 8/9/2015). The ability of the public service to develop and implement public policies is crucial to the achievement of its development goals including good governance (The Punch 15/8/2015).

With the faithful implementation of the New Public Management (NPM) and the in-road Information and Communication Technology (ICT) has made into the public sector, particularly, the E-governance model of service delivery, there is bound to be better performance of the public service in meeting the demands of good governance in the country. If the essence of any government is the people, then their concerns should at all times be the priority of government (Akhakpe 2016, Igbokwe Ibeto 2015, Oni and Oni 2016). Therefore, cultivating a strong partnership with the people by getting them involved in the administration of public affairs is a sine-quo-non to efficient and effective governance in the country (Akhakpe 2014).

Above all, constant and continuous reform of the public sector should be made part and parcel of the operational plans of the service. This is because the public service that serves the colonial system should be different from that of the post-colonial and dynamic global systems. This is perhaps, what Amuwo (1997) meant when he averred that "...whereas administration in the developed West is meant to maintain an already acquired and satisfactory level of socioeconomic development the same administrative mechanism copied by developing Africa should serve as catalyst for development." It follows therefore, that administrative mechanisms like the public service in Africa and Nigeria should understand that their roles are different from their homologue in the developed West. The public service is the driver of socioeconomic development, and governance. Therefore, it should strategise to bring all these to bear on the State and society in Nigeria. 


\section{CONCLUSION}

We have dealt with the issue of the public service as a catalyst for good governance in a neocolony like Nigeria. The paper recognizes that inherited political institutions like the public service in Nigeria needs some adaptation to make in order to remain relevant in a different context like Nigeria. Therefore, to serve the goals of good governance, it should embrace international best practices such as ICT, the NPM, professionalism and innovation, capacity building, articulation and pursuit of a vision for the public service and prioritization of merit in appointment of seasoned technocrats and econocrats to drive the vision of the public service. It recognizes that there are pitfalls to realizing these visions of the service such as attitudinal constrain, poor policy implementation, resource deficits, poor remuneration of staff, etc. However, with dedication and commitment to set goals and involvement of the people in all activities of government, these pitfalls are surmountable.

\section{References}

Ademolekun, L. (1997). Politics and Administration in Nigeria. Ibadan: Spectrum Book Limited.

Afegbua, S. (2015) "Professionalization and Innovations in Nigerian Public Service: How for the Dream of Success? Africa's Public Service Delivery and Performance Review Journal Vol. 3 - Issue 2.

Ake, C. (1994). Democratization of Disempowerment in Africa (ASS Occasional Monograph. No. 1 Lagos: Malthouse Press Ltd.

Akhakpe, I. B. (2014) “Public Policy, Interest Groups and Sustainable Development in Nigeria. Review of Public Administration and Management 3 (6).

Akhakpe, I. B. (2016)"Public Policy and Sustainable National Development in Nigeria" Nigeria's Fourth Republic: Challenges and Possibilities. International Journal of Management Perspective 13 (1).

Almond, G. et al (2007). Comparative Politics Today. New Delhi: Dorhing Kinderslay.

Amuwo, K. (1997). "Critical perspectives on structure, nature and role of Public Bureaucracy in Nigeria". The Quarterly Journal of Administration 29 (2)

Bamgbose, A. and Oloruntele, a. (2017) "The Role of the State in Public Sector Management" in C. Maduabum and I. Akhape (Eds.). The Dynamics of Public Sector Management: A Reader. Ibadan: John Archer Publishers Limited.

Bankole, A. (2010). Public Sector Human Resource Management. Lagos; Statement Branding.

Basil, D. (1997). The Black Man's Burden: Africa and the Cause of the Nigerian State. Ibadan: Spectrum Books Limited.

Dibie, A. A. (2014) Public Administration: Theory, Analysis and Application. Ilishan-Dams: Babcock University Press.

Dwivedi, O. P. (2001). "Challenges in Public Administration from Developing Nations" - New York: United Nations General Assembly, Second Committee.

Echikwonye, R. A. and Beetseh, K. (2011). "The Role of Public Policy making and development in Nigeria”. Journal of Social Science and Public Policy Vol. 3

Ekeh, P. (1980). Colonialism and Social Structure. Ibadan: University of Ibadan. An Inaugural Lecture.

Federal Government of Nigeria (FGN). The 1999 Constitution of the Federal Republic Abuja: Government Press.

Fukuyama, F. (2012). The Origin of Political Order. London: Profile Books Limited.

Gboyega A. (1992) "Civil Service Reforms in Nigeria and the Quest for Efficiency, Responsiveness and Accountability: A Critique”. Journal of Nigerian Public Administration and Management. Vol. 2 (2).

Henry, N. (2007) Public Administration and Public Affairs. Ncon Delhi: Prentice Hall Private Limited Igbokwe, C. J. (2015) Re-inventing Nigeria's Public Sector: A review of National Agency for Food, Drug Administration and Control (NAFDAC)". Africa's Public service delivery and Performance Review Journal Vol. 3. Issue 2.

Izbuzor, 0. (1998). "Reflections on Allson Ayida's Proposal on The Reforms of the Nigerian Civil Service". The Nigerian Social Sciences 1 (1) 
Kaufmann (2000). "Improving Governance and Controlling Corruption: New Empirical Frontiers and Case for Collective Action" in I. Gabriel, Rosta Penburst and M. Thomas (Eds.). The Role of Bilateral Donors in fighting corruption. New York: The World Bank.

LaPalombara, J. (1967). Bureaucracy and Political Development. New Jersey: Princeton: Princeton University Press.

Maduabum C. (2014). "Innovative Management Behaviour" in C. P. Maduabum (Ed.) Contemporary Issues on Management in Organisations. A Book of Readings. Ibadan: Spectrum Books Limited.

Maduabum, C. (2006) Reforming Government Bureaucracies in Nigeria. Lagos: Administrative and Staff College of Nigeria (ASCON).

Maduabum, C. (2014). "What has Public Administration Got to Do With It". An Inaugural Lecture. Abuja: National Open University of Nigeria (NOUN).

Nzongola-Ntalaja, G. (1997). "The State and Democracy in Africa” in G. Nzongola-Ntalaja and M. Lee (Eds.). The state and democracy in Africa. Harare: SAPES Books.

Olaopa, T. (2010), Public Service Reforms in Africa. Ibadan: University Press PLC.

Olugbemi, S. (1979). "The civil service" an outsider's view in O. Oyediran (Ed.) Nigerian Government and Politics Under military Rule 1966 -1979. London: The Macmillan Press.

Oni, S. and Oni, A. (2015). "E-government and administrative efficiency in Nigeria's Public Service" in P. Idaraesit, Akpan-Obong, A. Ayo and A. Adebiyi (Eds.). Issues and Concepts of E-Governance in Nigeria: A Reader. Ota: Covenant University Press.

Osaghae, E. E. (2002). The Crippled Giant: Nigeria Since Independence. Ibadan: John Archers Publishers Limited.

Sarumi, 0. 0. (2016) "Exploring the Act of Diplomacy and the Implication of Communication in Good Governance". Paper presented at the Induction Lecture of the Institute of Public Diplomacy and Management in June.

United Nations Development Programme (UNDP) 1997 “Reconceptualising Governance: New York: United Nations.

Yusuf, B. and Idowu, K. (2017). "Work Ethics and Public Sector Management" in C. Maduabum and I. Akhakpe (Eds.) The Dynamics of Public Sector Management: A Reader. Ibadan: John Archers Publishers Limited.

The Punch (Newspaper, Lagos). "Civil Servants are Corrupt and Lazy" September 5.

The Punch (Newspaper, Lagos). "How Nigeria can get out of Recession" October, 25, 2016 